\title{
Pengaruh model pembelajaran problem based learning terhadap hasil belajar siswa kelas $X$ pada materi struktur atom di SMA katolik santa rosa de lima tondano
}

\author{
Chrisly Durant ${ }^{* a}$, Emma J. Pongoh ${ }^{a}$, Sonny Lumingkewas ${ }^{a}$ \\ a Universitgs Negeri Manado, Tondano, 95618, Indonesia
}

\begin{tabular}{|c|c|}
\hline INFO ARTIKEL & ABSTRACT \\
\hline Diterima 21 Mei 2019 & \multirow{11}{*}{$\begin{array}{l}\text { Problem Based Learning model is a problem-based learning model that exposes } \\
\text { students to practical problems to be solved that focus on the final results. The purpose } \\
\text { of this study is to find out whether the Problem Based Learning learning model on } \\
\text { atomic structure material is better than conventional learning models. The population } \\
\text { in this study were all class X students of Santa Rosa de Lima Tondano Catholic High } \\
\text { School. The sample of this study was class XA and class XB Catholic School Santa } \\
\text { Rosa de Lima Tondano with the number of students } 30 \text { people, for the experimental } \\
\text { class } 15 \text { people and the control class } 15 \text { people, in the even semester the academic year } \\
\text { 2018/2019. Hypothesis testing uses the t-test to see differences in student learning } \\
\text { outcomes between the experimental class and the control class. Based on the results of } \\
\text { the study obtained the value of t_count (4.21)>t_table (1.701) at the real level } \alpha= \\
\text { 0.05. So that H_0 is rejected and H_1 is accepted. where the average value obtained } \\
\text { in the experimental class } 82.66 \text { and the average value for the control class 71.33. So } \\
\text { the conclusion is that there is a positive effect of the implementation of the Problem } \\
\text { Based Learning learning model on atomic structure material on student learning } \\
\text { outcomes at Santa Rosa de Lima Tondano Catholic High School. }\end{array}$} \\
\hline Disetujui 15 Juni 2019 & \\
\hline Key word: & \\
\hline Problem Based Learning, & \\
\hline Atomic Structure & \\
\hline & \\
\hline Kata kunci: & \\
\hline $\begin{array}{l}\text { Problem Based Learning, } \\
\text { Struktur Atom }\end{array}$ & \\
\hline & \\
\hline & \\
\hline & \\
\hline
\end{tabular}

ABSTRAK

Model pembelajaran Problem Based Learning adalah model pembelajaran berbasis masalah yang menghadapkan siswa pada permasalahan praktis untuk dipecahkan yang menitik beratkan kepada hasil akhir. Tujuan penelitian ini adalah untuk mengetahui apakah model pembelajaran Problem Based Learning pada materi struktur atom lebih baik dari model pembelajaran konvensional. Populasi dalam penelitian ini adalah seluruh siswa kelas $X$ SMA Katolik Santa Rosa de Lima Tondano. Sampel penelitian ini adalah kelas XA dan kelas XB SMA Katolik Santa Rosa de Lima Tondano dengan jumlah siswa 30 orang, untuk kelas eksperimen 15 orang dan kelas kontrol 15 orang, pada semester genap tahun ajaran 2018/2019. Pengujian hipotesis menggunakan uji-t untuk melihat perbedaan hasil belajar siswa antara kelas eksperimen dan kelas kontrol. Berdasarkan hasil penelitian diperoleh nilai $t_{\text {hitung }}(4,21)>t_{\text {tabel }}(1,701)$ pada taraf nyata $\alpha=0,05$. Sehingga $H_{0}$ ditolak dan $H_{1}$ diterima. dimana diperoleh nilai rata-rata pada kelas eksperimen 82,66 dan nilai rata-rata untuk kelas kontrol 71,33 . Maka kesimpulannya terdapat pengaruh yang positif dari pelaksanaan model pembelajaran Problem Based Learning pada materi struktur atom terhadap hasil belajar siswa di SMA Katolik Santa Rosa de Lima Tondano.

chrislydurant@gmail.com

${ }^{*}$ Telp:

\section{Pendahuluan}

Pendidikan merupakan salah satu faktor penting bagi manusia dalam menjalani kehidupan. Untuk membangun masyarakat terdidik, cerdas, mau tidak mau harus merubah paradigma dan sistem pendidikan. Dalam 
pembelajaran, guru harus memahami materi pelajaran yang akan diajarkan agar siswa lebih mudah memahami materi pelajaran tersebut. Dunia pendidikan merupakan proses pembelajaran terus-menerus mengalami perkembangan dari tahun ke tahun. Hal ini disertai dengan adanya upaya peningkatan kualitas pendidikan di sekolah. Di samping itu, guru sebaiknya memahami berbagai model pembelajaran yang dapat merangsang kemampuan semua siswa untuk belajar dengan perencanaan pengajaran yang matang.

Belajar adalah suatu usaha sadar yang dilakukan oleh individu dalam perubahan tingkah laku baik melalui latihan dan pengalaman yang menyangkut aspek-aspek kognitif, afektif dan psikomotorik untuk memperoleh tujuan tertentu [1]. Penggunaan model belajar yang sesuai dengan mata pelajaran dan materi yang diajarkan akan memberikan dampak positif terhadap hasil belajar siswa dan akan tercapai hasil belajar yang baik diperlukan suasana belajar mengajar yang tepat, sehingga siswa dapat meningkatkan aktivitas belajarnya.

Problem based learning merupakan salah satu metode alternatif yang dapat digunakan untuk mengatasi permasalahan tersebut, karena dari penelitian-penelitian sebelumnya mengungkapkan bahwa PBL dalam pembelajaran kimia dapat meningkatkan ketiga kemampuan tersebut. Pada hasil observasi yang dilakukan oleh penulis di SMA Katolik Santa Rosa de Lima Tondano tentang proses belajar mengajar khususnya pelajaran kimia, telah ditemukan bahwa sebagian siswa tidak fokus, cenderung diam, kurang siap menerima pelajaran, dan tidak berani menjawab ketika diberikan pertanyaan oleh guru. Guru juga kurang menggunakan media pembelajaran yang berinovasi sehingga siswa merasa bosan dan kurang semangat dalam menjalani kegiatan pembelajaran. Siswa hanya mendengar guru menyampaikan materi pelajaran, sehingga peran guru lebih dominan dalam proses pembelajaran di kelas. Hal ini berdampak pada pencapaian hasil belajar yang didapat para siswa menjadi kurang maksima, selain itu penguasaan siswa juga masih rendah terhadap materi kimia itu sendiri. Hal ini disebabkan cara mengajar guru yang masih mendomonasi atau terfokus pada dirinya sedangkan, kepada siswa sedikit disaat mengajar sehingga siswa menjadi pasif dan hanya mendengarkan saja.

Pembelajaran dikatakan berhasil apabila $85 \%$ dari jumlah siswa yang mengikuti proses pembelajaran mampu mencapai KKM yang ditetapkan untuk mata pelajaran. Untuk mengatasi permasalahan siswa tersebut maka peneliti memilih model pembelajaran problem based learning sebagai metode pendekatan untuk pemecahan masalah. Metode ini belum pernah di terapkan di SMA Katolik Santa ROSA de LIMA Tondano.

\section{Metode}

Untuk memperoleh informasi dalam penelitian ini peneliti menggunakan metode penelitian eksperimen. Bentuk yang digunakan adalah True experimental, posttest-only control design. Di mana sampel yang digunakan diambil dengan cara simple random sampling dari populasi untuk membentuk kelas eksperimen dan kelas kontrol.

Tabel 1. Posttest-Only Control Design

\begin{tabular}{ccc}
\hline $\mathrm{R}$ & $\mathrm{X}$ & $\mathrm{O}_{2}$ \\
\hline $\mathrm{R}$ & & $\mathrm{O}_{4}$ \\
\hline
\end{tabular}

Keterangan :

$\mathrm{R}$ : sampel kelas eksperimen dan kelas kontrol

$\mathrm{O}_{2}$ : tes akhir (posttest) kelas eksperimen

$\mathrm{O}_{4}$ : tes akhir (posttest) kelas kontrol

$X$ :perlakuan pada kelas eksperimen dengan pembelajaran model tipe PBL

Dalam desain ini terdapat dua kelompok yang masing-masing dipilih secara random (R). Kelompok pertama diberi perlakuan dan kelompok yang lain tidak. Kelompok yang di beri perlakuan disebut kelompok eksperimen dan kelompok yang tidak diberi pelakuan disebut kelompok kontrol [2].

\section{Hasil dan Pembahasan}

Hasil penelitian diperoleh melalui proses penelitian yang telah dilakukan di SMA Katolik Santa Rosa de Lima Tondano, dengan sampel dua kelas yaitu kelas XA sebagai kelas eksperimen dan kelas XB sebagai kelas kontrol. Data penelitian berupa data hasil nilai posttest pada kelas eksperimen dan kelas kontrol dengan jumlah responden untuk kelas eksperimen 15 orang dan kelas kontrol 15 orang menggunakan soal objektif dengan jumlah 10 
butir soal. Hasil analisis skor dari data hasil belajar siswa kelas eksperimen dan kelas kontrol dapat dilihat pada Tabel 2.

Tabel 2. Data Penelitian Hasil Belajar Posttest kelas eksperimen dan kelas kontrol (kelas XA dan kelas XB).

\begin{tabular}{clll} 
& & & \\
\cline { 3 - 4 } NILAI & & Kelas eksperimen & Kelas kontrol \\
\cline { 2 - 4 } & & Post-test & Post-test \\
\hline 1 & Skor Minimum & 60 & 50 \\
2 & Skor Maksimum & 100 & 100 \\
3 & Rata-Rata & 82,66 & 71,33 \\
4 & Simpangan Baku & 13,34 & 15,05 \\
5 & Varians & 57,30 & 51,55
\end{tabular}

Untuk 10 butir soal posttest yang diujikan kelas eksperimen memperoleh skor minimum 60 dan skor maksimum 100, kelas kontrol memperoleh skor minimum 50 dan skor maksimum 100. Dapat dilihat pada kelas eksperimen memperoleh nilai rata-rata 82,66 dan kelas kontrol memperoleh nilai rata-rata 71,33 .

\section{Uji Instrument Penelitian}

Instrumen yang diuji adalah Posttest (Test Akhir) yang diuji validitas dan reliabilitasnya.

\section{Uji Validitas}

Pada tahap ini dilakukan uji validitas butir soal yang akan digunakan untuk mengukur pemahaman konseptual siswa. Dari 15 butir soal yang diuji cobakan pada 15 responden didapat 10 butir soal valid dan 5 butir soal tidak valid dengan kriteria $r_{\text {hitung }}>r_{\text {tabel }}$.

\section{Uji Reliabilitas}

Pada tahap ini di lakukan uji realibilitas dengan teknik belah dua split half yang di analisis dengan rumus Sperman Brown. Berdasarkan perhitungan diperoleh nilai reliabilitas instrumen sebesar 1,93.

\section{Uji Normalitas}

Pengujian normalitas digunakan untuk melihat apakah sampel yang digunakan dalam penelitian ini terdistribusi normal atau tidak. Pengujian normalitas dalam penelitian menggunakan Uji Liliefors dengan $\alpha=0,05$. Dengan kriteria jika Lhitung > Ltabel maka data berdistribusi tidak normal, dan jika Lhitung $<$ Ltabel maka data berdistribusi normal.

Berikut adalah ringkasan pengujian normalitas kelas eksperimen dan kelas kontrol. Berdasarkan Tabel 3 dapat dilihat nilai Lhitung < Ltabel pada taraf signifikan $=0,05$. Nilai dari Lhitung pada kelas eksperimen sebesar 0,079 dan nilai Lhitung pada kelas kontrol sebesar 0,201 dengan responden pada masing-masing kelas adalah 15 orang, maka dapat disimpulkan sesuai dengan kriteria bahwa dua kelas yaitu kelas eksperimen dan kelas kontrol berdistribusi normal.

Tabel 3. Ringkasan Uji Normalitas

\begin{tabular}{llcccc}
\hline No. Sampel & N & Lhitung & Ltabel & Kesimpulan \\
\hline 1 & $\begin{array}{l}\text { Kelas } \\
\text { Eksperimen }\end{array}$ & 0,079 & 0,228 & Normal \\
\hline 2 & Kelas kontrol 15 & 0,201 & 0,228 & Normal \\
\hline
\end{tabular}

\section{Uji Homogenitas}

Pengujian homogenitas ini untuk melihat apakah kedua sampel bersifat homogen. Uji yang digunakan adalah Uji $\mathrm{F}$ dengan $\alpha=0,05$ dan $\mathrm{n}$ adalah 15. Jika harga Fhitung lebih kecil $(<)$ dari Ftabel maka data yang di analisis homogen, bila Fhitung lebih besar (>) dari tabel maka varian tidak homogen. Pengujian homogenitas hasil tes akhir menggunakan Microsoft excel. data ringkasan uji homogenitas dapat dilihat pada Tabel 4.

Tabel 4. Ringkasan Uji Homogenitas

\begin{tabular}{lccc}
\hline Statistik & Kls. & Kontrol & \multicolumn{2}{c}{ Kls. Eksperimen } \\
& & & \\
\hline Jlh responden & 15 & & 15 \\
Rata-rata & 82,66 & & 71,33 \\
Varians S2 & 57,30 & & 51,55 \\
Fhitung & & 1,11 & \\
Ftabel & & 2,54 & \\
\hline
\end{tabular}

Dari data diatas, dapat dilihat bahwa kedua kelas bersifat homogen. Hal ini dilihat dari $F_{\text {hitung }}<\mathrm{F}_{\text {tabel. }}$.

\section{Uji Hipotesis}

Pengujian hipotesis yang digunakan dalam penelitian ini adalah uji $\mathrm{T}$ dengan $\alpha=$ 0,05. Uji $\mathrm{T}$ ini dilakukan untuk melihat apa terdapat perbedaan antara kedua kelas. Berikut adalah ringkasan uji hipotesis hasil belajar. 
Berdasarkan tabel 5 dapat dilihat bahwa nilai rata-rata hasil belajar di kelas eksperimen adalah 82,66 , varians sebesar 57,30 sedangkan pada kelas kontrol nilai rata-rata hasil belajar sebesar 71,33, dan varians sebesar 51,55 dengan jumlah responden masing-masing kelas adalah 15 orang. nilai dari thitung pada taraf signifikan $\alpha$ $=0,05$ adalah 4,21 >ttabel 1,701. Oleh karena itu dapat disimpulkan sesuai dengan kriteria bahwa jika thitung $>$ tabel maka hipotesis yang diterima adalah adalah terima $\mathrm{H}_{1}$, didapat bahwa thitung $=4,21$ tabel $(0,05, \mathrm{dk}=28)=2,048$. Jadi, thitung $>$ tabel $\mathrm{H}_{1}$ diterima dan $\mathrm{H}_{0}$ ditolak. Dilihat juga pada rata-rata hasil belajar siswa, dimana kelas eksperimen $=82,66$ dan kelas kontrol $=71,33$. Hasil ini menggambarkan bahwa terdapat perbedaan antara kelas eksperimen dan kelas kontrol. Dimana kelas eksperimen lebih tinggi daripada kelas kontrol. Dapat dilihat pada Tabel 5.

Tabel 5. Ringkasan Uji Hipotesis Hasil Belajar

\begin{tabular}{cccc}
\hline \multicolumn{2}{c}{ Kelas Eksperimen } & \multicolumn{2}{c}{ Kelas Kontrol } \\
\hline $\mathrm{N}$ & 15 & $\mathrm{~N}$ & 15 \\
$\mathrm{n}-1$ & 14 & $\mathrm{n}-1$ & 14 \\
Mean & 82,66 & Mean & 71,33 \\
Varians & 57,30 & Varians & 51,55 \\
thitung & 4,21 & ttabel & 1,701 \\
Kesimpulan & Terima $\mathrm{H}_{1}$ & & \\
\hline
\end{tabular}

\section{Pembahasan}

Penelitian ini dilakukan di SMA Katolik Santa Rosa de Lima Tondano pada bulan Oktober 2018 terdiri dari 2 kelas sebagai sampel yaitu kelas XA yang menjadi kelas eksprimen dengan diterapkan model pembelajaran PBL dan kelas $\mathrm{XB}$ sebagai kelas kontrol dengan model pembelajaran konvensional. Penelitian ini dilakukan masing-masing selama 2 kali pertemuan dengan materi yang digunakan adalah struktur atom.

Pada kelas eksperimen digunakan model pembelajaran PBL. Sebelum pembelajaran dimulai, siswa diberikan sedikit penjelasan mengenai tujuan dan strategi pembelajaran PBL yang akan digunakan. Setelah selesai penyampaian, siswa diberika 10 butir soal struktur atom. Selesai pemberian soal siswa diberikan kesempatan untuk memberikan pertanyaan apabila ada soal yang kurang dimengerti. Setelah itu siswa diminta untuk mengumpulkan hasilnya.
Pada kelas kontrol diberikan pembalajaran kimia tanpa menggunakan model PBL. Guru hanya menjelaskan semua informasi tentang materi struktur atom, sedangkan siswa hanya memperhatikan dan mendengarkan saja yang dijelaskan oleh guru. Kemudian siswa diberikan contoh soal untuk mengetahui sejauh mana ketercapaian indikator pembelajaran pada kelas kontrol. Untuk mengetahui hasil belajar siswa pada pertemuan akhir siswa diberikan posttest. Berikut adalah data hasil posttest yang diberikan pada kelas eksperimen dan kelas kontrol dapat dilihat pada Tabel 6.

Tabel 6. Ringkasan hasil posttest kelas eksperimen dan kelas kontrol

\begin{tabular}{ccccc}
\hline N & Eksperimen & Jumlah & Kontrol & Jumlah \\
\hline 1 & 60 & $2-$ siswa & 50 & $2-$ siswa \\
2 & 70 & $2-$ siswa & 60 & $3-$ siswa \\
3 & 80 & $4-$ siswa & 70 & $5-$ siswa \\
4 & 90 & $4-$ siswa & 80 & $3-$ siswa \\
5 & 100 & $3-$ siswa & 100 & $2-$ siswa \\
\hline
\end{tabular}

Dari data di atas dapat dilihat bahwa pada kelas eksperimen terdapat 2 siswa untuk nilai 60, 2 siswa untuk nilai 70, 4 siswa untuk nilai 80, 4 siswa untuk nilai 90, dan 3 siswa untuk nilai 100, dengan nilai minimal 60 dan nilai maksimal 100, untuk rata-rata yang diperoleh pada kelas eksperimen yaitu 82,66 . Pada kelas kontrol terdapat 2 siswa untuk nilai 50, 3 siswa untuk nilai 60, 5 siswa untuk nilai 70, 3 siswa untuk nilai 80, dan 2 siswa untuk nilai 100, dengan nilai minimal 50 dan nilai maksimal 100, untuk rata-rata yang diperoleh pada kelas kontrol yaitu 71,33 . Hal ini menunjukan bahwa hasil belajar kimia materi struktur atom untuk kelas X pada kelas eksperimen di SMA Katolik Santa Rosa de Lima Tondano lebih baik dibandingkan dengan hasil belajar pada kelas kontrol.

Dari data posttest yang diberikan pada kelas eksperimen dengan menggunakan model pembelajaran PBL terdapat 11 siswa telah mencapai KKM atau telah memahami materi struktur atom yang diajarkan sedangkan 4 orang siswa belum tuntas atau belum memahami materi tata nama senyawa yang diberikan. Hal ini menunjukan bahwa hasil belajar kimia pada materi struktur atom dengan menggunakan model pembelajaran PBL pada 
kelas X di SMA Katolik Santa Rosa de Lima Tondano termasuk dalam kategori baik. Demikian dari hasil pengamatan menunjukan bahwa masih ada peserta didik yang tidak tuntas dalam hasil belajarnya. Ini disebabkan karena pemahama siswa terhadap materi yang diberikan belum begitu optimal.

Dari perhitungan pengujian hipotesis penelitian diperoleh $t_{\text {hitung }}$ sebesar 4,21 nilai tersebut selanjutnya dibandingkan dengan nilai $t_{\text {tabel }}$, terlebih dahulu menentukan derajat kebebasan (dk) dengan rumus $\mathrm{n} 1+\mathrm{n} 2-2=15$ $+15-2=28$. Besarnya $t_{\text {tabel }}$ dengan $\mathrm{dk}=28$ pada taraf signifikan 0,05 sebesar 2,048, karena $t_{\text {hitung }}$ $>t_{\text {tabel }}$ pada taraf signifikan 0,05 maka $H_{0}$ ditolak dan $H_{1}$ diterima. Hasil ini menunjukan bahwa terdapat perbedaan hasil belajar antara kelas eksperimen dan kelas kontrol.

\section{Ucapan terimakasih}

Disampaikan banyak terima kasih kepada seluruh dosen di Jurusan Kimia Fakultas Matematika dan Ilmu Pengetahuan Alam Universitas Negeri Manado dan juga SMA N 9 Halmahera Timur yang berperan penting dalam pelaksanaan penelitian ini.

\section{Kesimpulan}

Berdasarkan data hasil penelitian dan analisis data yang telah diuraikan, maka dapat disimpulkan bahwa terdapat pengaruh model pembelajaran PBL terhadap hasil belajar siswa kelas X SMA Katolik Santa Rosa de Lima Tondano dengan rata-rata nilai yang dicapai 82,66 untuk kelas eksperimen dan 71,33 untuk kelas kontrol.

\section{Daftar Pustaka}

1. Abdillah, H. Pengertian Belajar dari Berbagai Sumber. ALFABETA : Bandung, Indonesia, 2002. ISBN.

2. Sugiyono. Metode Penelitian Pendidikan, (Pendekatan Kuantitatif, Kualitatif, dan R\&D). 2016. ALFABETA : Bandung, Indonesia, ISBN. 